
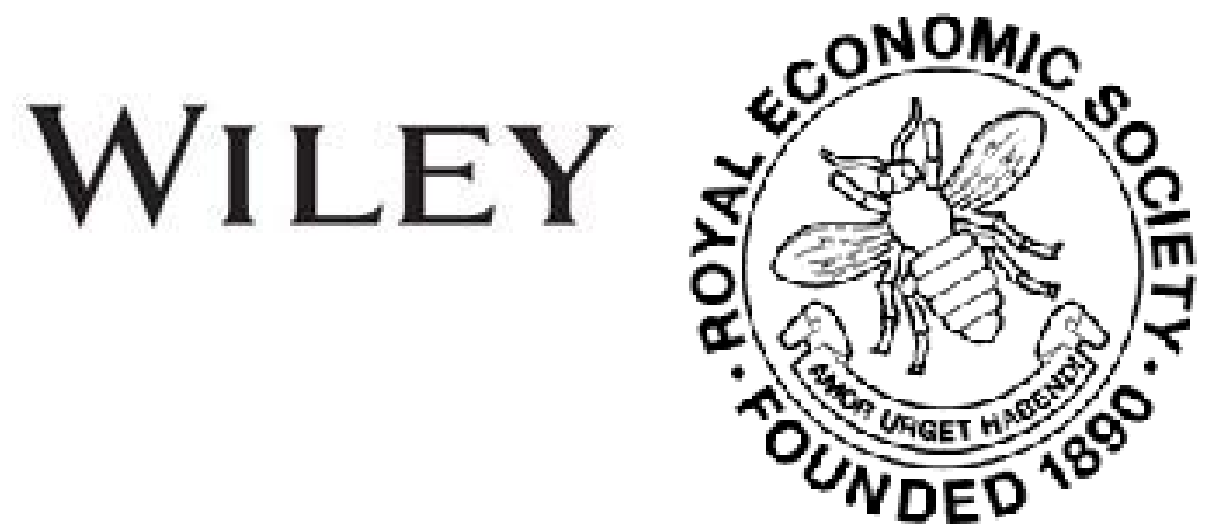

Mr. Goschen's Currency Proposals

Author(s): H. S. Foxwell

Source: The Economic Journal, Vol. 2, No. 5 (Mar., 1892), pp. 139-156

Published by: Wiley on behalf of the Royal Economic Society

Stable URL: http://www.jstor.org/stable/2955956

Accessed: 26-06-2016 11:00 UTC

Your use of the JSTOR archive indicates your acceptance of the Terms \& Conditions of Use, available at

http://about.jstor.org/terms

JSTOR is a not-for-profit service that helps scholars, researchers, and students discover, use, and build upon a wide range of content in a trusted digital archive. We use information technology and tools to increase productivity and facilitate new forms of scholarship. For more information about JSTOR, please contact support@jstor.org.

Wiley, Royal Economic Society are collaborating with JSTOR to digitize, preserve and extend access to The Economic Journal 


\section{NOTES AND MEMORANDA}

\section{Mr. Goschen's Currency Proposals. ${ }^{1}$}

Mr. Goschen's currency proposals, first laid before the public in his memorable Leeds speech, at a time when the circumstances connected with the Baring difficulty had left a very painful impression of the inadequacy of our banking arrangements, have now been for more than a year under discussion. They have been submitted to very general and various criticism, and have been further developed and explained by Mr. Goschen himself in an address at the London Chamber of Commerce, and in certain supplementary letters. Many details of the scheme, it is true, still remain undetermined, together with one or two points which can hardly be regarded as details. But it should be possible now to form a fair judgment as to the general nature and bearings of Mr. Goschen's proposals; and it will be convenient at the same time to consider the substantial effect of the more important criticisms and suggestions to which they have given rise.

Mr. Goschen's main purpose is connected not so much with currency as with banking. He starts from the position, practically conceded to him by all his critics, that our metallic banking reserve is inadequate Admitting, and indeed insisting, that much may be done by the bankers themselves to remedy this weakness, Mr. Goschen proposes that the State should make a contribution towards the desired end by the formation of a second or relief reserve, to be accessible, under special conditions, in times of special strain. This reserve is to be formed by the issue of legal tender $£ 1$ notes, which so far as they might become current would take the place of sovereigns as the pocket money of the nation; and the sovereigns so withdrawn from the circulation would for the most part be held by the Issue Department, intact in ordinary times, but available for banking purposes, subject to conditions not yet fully specified, in times of exceptional pressure.

Mr. Goschen observes that neither of the proposals which jointly

1 Speech at Leeds, 28 January, 1891. Effingham Wilson. 8vo.

Speech at London Chamber of Commerce, December 2, 1891, and Letter to the Governor of the Bank of England. Revised Report published by the Chamber.

Letter to Mr. Samuel Montagu, M.P., January 28, 1892. Journal of the Institute of Bankers, February, 1892. 
constitute his scheme is, in principle, new. The proposal to give greater elasticity to the banking reserve, and the proposal to issue $£ 1$ notes, have both been put forward again and again by the highest authorities, and supported by the weightiest considerations. The novelty, he says, consists in the combination of the proposals, so that the one makes the other possible. He might have added that the joint proposals are introduced at a time when the light sovereigns are in process of withdrawal for recoinage, a further combination not less novel and convenient.

The details of the scheme, so far as they are before us, may best be given by an extract from the letter addressed by Mr. Goschen to the Governor of the Bank of England on December 3, 1891.

"The Bank of England is at present authorized to issue $£ 16,450,000$ on securities. Beyond that, all notes must be represented by gold. The average amount of gold in the Issue Department for the years $1881-90$ may be taken as between $£ 21,000,000$ and $£ 22,000,000$. Say, to obtain round figures, $£ 21,550,000$, which if added to the $£ 16,450,000$ - the authorized amount of the fiduciary issue-would give a total of $£ 38,000,000$, representing the average total issue under the provisions of the Act of 1844. I would disturb nothing up to this point beyond authorizing the issue of $£ 1$ notes under precisely the same conditions as those under which notes of higher denominations are issued at present. But beyond this limit of $£ 38,000,000$, I would authorize the issue of notes under the conditions which I have sketched, namely, $£ 4$ on gold to $£ 1$ on securities.

“The proposal may be stated in another and perhaps a simpler way, by describing the authority as commencing when the stock of gold in the Issue Department of the Bank of England stands at $£ 21,550,000$.

"If an additional sum of $£ 25,000,000$ were issued in the proportion of $£ 4$ on gold to $£ 1$ on securities, the addition to the stock of gold would be $£ 20,000,000$, bringing the total to $£ 41,550,000$, and the position would be as follows :-
' Total notes-

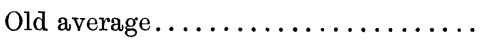
Additional issue................
$\stackrel{\mathfrak{E}}{38,000,000}$
This total would be issued against gold
$25,000,000$
and securities respectively in the fol-
lowing proportions :-
Total stock of gold-
Under the old provisions ...........
Add $\frac{4}{5}$ ths of $£ 25,000,000$ under the new
provisions $\ldots \ldots \ldots \ldots \ldots \ldots \ldots$.
$21,550,000$
$20,000,000$
Notes issued against gold...........
Notes issued against securities-
Previous amount ............. 16,450,000
Add $\frac{1}{5}$ th of $£ 25,000,000 \ldots \ldots \ldots \ldots \ldots \quad 5,000,000$
Total notes issued against securities.... $21,450,000$
Total notes as above $\ldots \ldots \ldots \ldots \quad \longdiv { 6 3 , 0 0 0 , 0 0 0 }$ 
"The contrast between the new and the old situation would be this :-

"We should have $\$ 41,550,000$ of gold at the Bank instead of $£ 21,550,000$, and the increase in the fiduciary issue would be only $£ 5,000,000$; and that increase would be due to the introduction of $£ 1$ notes, which, if once acclimatized, would be far less likely to be presented for payment than $£ 5$ notes.

"I have taken the amount of $£ 25,000,000$ simply for the purpose of illustration. It is not necessary to assume that this amount would be reached.

"I should add to the statements which I made yesterday, that, if, contrary to my expectation, the additional issue under the new terms should reach $£ 50,000,000$, I should be prepared to require any further issues beyond that sum to be covered in full by gold. Such a provision would meet the objection, that an indefinite amount of gold might be lost to the country under my plan.

"The second part of the scheme is as follows:-If the addition to the stock of gold through the issue of $£ 1$ notes should bring the total stock up to $£ 30,000,000$, a point which would be reached by the issue of $£ 10,000,000$ under the new conditions, I should be prepared to give certain additional powers of issue in times of emergency, which, under the present system, it would not be justifiable to grant. I would authorize the Bank to strengthen the reserve in the Banking Department by the issue of additional notes against securities, on paying to the Government a high rate of interest, to be fixed by law. I stated that the rate of interest must be neither so high as to make the permission inoperative, nor so low as to encourage people to speculate up to it.

"This additional authority to the Bank is intended to take the place of, and prevent the necessity for, the Treasury letter, by which the Bank Charter Act has been several times suspended."

It will be observed that the scheme is one of considerable complication, and that Mr. Goschen's exposition leaves one matter of really fundamental importance undetermined. He has not specified the conditions on which his second reserve is to be accessible. Is the new reserve, in short, to be strictly a panic reserve, only available upon occasions of absolute crisis, such as have in past times involved the suspension of the Act of 1844 ; or is it to be generally available to meet all seriously mischievous monetary strains? The absence of definite information on a point so vital makes it difficult to understand the real nature of the scheme and consequently to express a decided opinion upon it. We may be pretty sure that Mr. Goschen is not likely to repeat the singular blunder made by Lord Sherbrooke in his abortive proposal of June 1873, when he fixed the minimum rate for the operation of his scheme at 12 per cent., and made the further conditions that a state of internal panic must exist, and that there must be no foreign drain of gold by the exchanges. It is difficult to conceive a case in which such conditions could be realized; and if they were, the mischief 
which a good banking system should avert would already have been done. Mr. Goschen has so clearly pointed out that the real aim of sound banking is not merely to avoid insolvency, but to secure stability of rates and regularity of accommodation to trade, that we might expect him to incline towards an elastic system of rates, with a moderate minimum, rather than to a high minimum, fixed at panic point. Some expressions in his speeches, however, seem to show a tendency in the other direction. The point must therefore be left open for the present.

Looking merely at the broad features of the scheme, it has certain obvious merits. It would undoubtedly increase the central stock of gold, while at the same time providing us with a new and convenient form of currency; and this by a costless operation, which would not make any fresh demands on the international gold market, or in any way unfavourably affect prices. To the extent to which the issue was fiduciary, gold might leave the country. The fiduciary issue, however, is scarcely an essential part of the scheme; and in any case the amount of gold so lost would be small, and the loss would be amply compensated by the greater efficiency for all banking purposes of the much larger portion which had been centralized. As Mr. Goschen puts it, forty millions at the centre are worth more than fifty millions in the pockets of the people. From the point of view of the note issue, the new position would clearly be a much stronger one. The £1 notes would be much less likely to be presented for conversion than the larger ones, and therefore the circulation as a whole would require a smaller proportionate reserve; but the actual percentage of bullion held against it would be increased. With the Issue Department thus strengthened, it becomes safe to make its reserve available in certain emergencies for the purposes of the Banking Department; and thus we secure what is practically an effective second reserve.

To avoid repetition, it is convenient to consider the details and the more disputable points of the scheme in connection with the criticisms it has received. These are by no means as instructive as might have been expected or desired. Take for instance the important meeting held at the Salters' Hall on January 21, 1892, for the purpose of expressing the opinion of the City of London. The meeting agreed to a resolution in favour of an increase of the reserve, negatived one declaring that this might be effected by an issue of $£ 1$ notes, and adopted an amendment that no change should be decided upon except after the fullest inquiry. It is not easy to understand what was intended by the amendment. The facts upon which Mr. Goschen's proposals are based are well known and not disputed; the principle has been under discussion for more than half-a-century. As The Economist of January 23, 1892, justly says, 'this lame and impotent conclusion will not raise the London bankers in the estimation of the public.' It adds that 'it is something to have gained from them this open acknowledgment of the fact that the cash reserves held to meet banking liabilities are too small, and 
must be strengthened, if the credit of the country is to be adequately maintained.' Upon this point of the inadequacy of the present reserve public opinion appears to be unanimous; nor could it well be otherwise in face of the facts. Mr. Goschen pointed out at Leeds that in the case of eleven large banks the proportion of cash (so-called) to liabilities was only $10 \cdot 3$ per cent. in 1889 , and that it had decreased 20 per cent. in ten years. Mr. Stanley Cobb shows that even this proportion is much too high, if taken to represent the actually available cash reserve. Allowing for the fact that bank reserves largely figure as deposits in other banks, and rightly excluding till-money from reserve, as required to carry on current business, he makes the real ratio about $2 \cdot 2$ per cent. now, as against 3.9 per cent. in 1879 , a decrease of 43 per cent. in the ten years. This may be compared with the estimate adopted by Jevons in 1875, who followed Mr. Inglis Palgrave in putting the available cash reserve at about 5 per cent. of the liabilities in 1873. Thus the proportion of reserve to liabilities is not only small, but it is steadily diminishing. While however it is prima facie probable that a banking system whose ultimate cash reserve is only some 2 or 3 per cent. of its liabilities will be extremely sensitive to disturbance, too much stress ought not to be laid upon the absolute smallness of the proportion. Only experience can tell us what is the real factor of safety in any particular kind of banking business. The most conclusive proof that our present reserve is inadequate is to be found in the nervous state of the money market in ordinary times, and in the fact that comparatively small withdrawals of gold, of a kind to which the London market is constantly liable, will produce unforeseen and mischievous advances in the current rate of discount.

As soon as we attempt to proceed beyond the proposition that the reserve should be increased, we are confronted with a truly discreditable chaos of opinions. The highest authorities put forward exactly opposite views, and Mr. Goschen might dispose of some of the most fundamental objections to his scheme by the simple process of pairing the objectors. There would perhaps be general agreement with the position of Mr. Stanley Cobb, that no considerable improvement will be made if the reserves are merely increased upon the present lines. Additional reserves, if deposited in other banks, as at present, would be represented by a very small relative increase in the ultimate cash reserve by the time they had filtered through to the cellars of the Bank of England. Mr. Pownall and some other critics have therefore suggested that the banks should keep their own reserve in Bank of England notes. There is no doubt that this would tend to increase the amount of reserve held, especially if the figures were required to be published. But it does not meet the real necessity of the case. In time, competition between the banks would lead to trading upon the reserves, which would gradually diminish again. What is really wanted is a second reserve-a reserve not accessible in ordinary times, and therefore effectively reserved for emergencies. 
This contention, and the proposal to avail himself of the strengthened Issue Reserve for the purpose, are of the essence of Mr. Goschen's scheme.

But here, of course, we are confronted with the inevitable Act of 1844, which, in terms at least, makes an absolute separation between the Issue and Banking Departments. In his attitude towards Peel's famous Act, Mr. Goschen occupies a position midway between those of two of his principal critics, Mr. Gairdner and Mr. Pownall. Mr. Gairdner prefers the Scottish system, in which notes are merged with deposits in one general mass of liability. He urges that the bullion and securities in the Issue Department were not by Peel's Act 'earmarked' against the notes. Legal opinions have been given in support of Mr. Gairdner's view; but it is abundantly clear that it strikes at the very 'root of Peel's legislation, by which the Issue Department was practically made an agency for the State. Accordingly we have Mr. Pownall taking precisely the opposite position. He considers that legislation should distinctly declare that the bullion and securities in the Issue Department are held exclusively as security for the notes; and indeed goes so far as to maintain that the notes should be issued wholly against bullion, the Government contributing towards this by the repayment to the Bank of the eleven millions odd still due from the State. The objections to this latter proposal scarcely require to be stated. It would lock up, at considerable expense, a further large stock of gold, thus causing a further pressure on the metal, while at the same time this stock was made useless for all banking purposes. The first proposal, no doubt, is a perfectly logical development of the Act of 1844. But it is obvious that it would absolutely prevent the use of the Issue Reserve contemplated by Mr. Goschen; and therefore we are forced to consider what is the reasonable position to adopt in reference to Peel's celebrated measure.

As regards some of its main provisions, the intention of the Act was quite clear, and there are ample materials for forming an opinion of their value. Sir Robert Peel seems to have been right in holding that legal tender notes, being practically coins, should only be issued subject to State regulation; wrong if he supposed that any regulation of such note issues could appreciably check the tendency to periodic overspeculation. He was also justified in holding that a great diversity of note issues, especially when issued by, and tending to maintain, a system of small localized banks, was inconvenient and undesirable. The natural shrinkage of the local issues in England supports this view. It is still more clear that in its enforcement of a hard and fast limit for the amount of the fiduciary circulation the Act was indefensibly empirical. It may be granted that the limit adopted was a very suitable one for the time, but it was not arranged so as to meet the requirements of an expanding population and trade. It is not so easy to judge of the fundamental provision of the Act, the separation of the Issue from the Banking Reserve, because we cannot be quite certain 
what was in the minds of those who were responsible for it. If they contemplated occasional suspensions of the Act, they were really creating a second reserve; and though we must consider their machinery rigid and clumsy, the principle was sound. If we are to take the Act literally as it stands, the provision cannot be defended. It involves the keeping of a large Issue Reserve of some $£ 20$ millions of gold, far more than is required to ensure the convertibility of the note, and yet absolutely useless for all banking purposes. The isolation of this mass of gold cannot be justified in theory; and in practice, circumstances have three times compelled the suspension of this part of the Act, whilst on numerous other occasions the need of a more elastic system has been severely felt. An admirable object lesson on the working of the Act as it stands was afforded by the events of November 1890. While a sum of nearly $£ 20$ millions was lying idle in the Issue Department, we were obliged, in order to avert disaster, to beg a loan of three millions from a foreign bank, to which, happily, the absolute restriction imposed by Peel's Act is unknown.

Upon the whole, then, it would seem that Mr. Goschen is well advised in the position he has taken on this much-contested matter of the separation of the Reserves. It is probable that the principle of complete fusion, advocated by Mr. Gairdner on the analogy of Scottish banking practice, would with our present English habits lead to a dangerous economy of gold. On the other hand, extreme partisans of the Act of 1844, like Mr. Pownall, would weaken our banking position by at the same time increasing and completely isolating the Issue Reserve. To a market so exposed to attack as that of London a second reserve is essential. The simplest way to constitute it is to form a strong issue reserve, separate and inaccessible in quiet times, in order that it may be really available in times of stringency.

But here we are met by a very general objection, which is supported by the authority of Mr. Inglis Palgrave. It is said that the Issue Reserve is being called upon to discharge two incompatible functions. How, it is asked, can Mr. Goschen expect it at the same time to secure his $£ 1$ notes, and to act as an ultimate banking reserve?

In the first place it might be replied that the functions are not incompatible. We know that in ordinary banking a reserve of $£ 100$ will secure not merely two but ten different liabilities of that amount, on the well-known principle of insurance, that the liabilities are not likely to be simultaneously pressed. Now there is no reason why notes should be discredited at a time of banking stringency. On the contrary, all recent history shows that notes have been readily current at such times; and indeed the usual mode of relieving a banking stringency is to make an additional issue of notes, and what is more, of notes against which no special reserve is held.

But a further answer is that the gold held against the $£ 1$ notes which Mr. Goschen proposes to issue is not, except in small part, necessary in order to secure their convertibility. These notes, so far as

No 5.-VOL. I 
they become current, will replace gold in circulation. They are not issued in such a way as to inflate the circulation, as for instance in the discount of bills; but for every $£ 100$ worth of notes issued, $£ 100$ will be withdrawn from the circulation; and if in consequence of the issue being partly fiduciary a portion of this amount is returned to the circulation, it will probably leave the country. These $£ 1$ notes, then, are not to be regarded as instruments of credit, but as cheap coins; sovereigns, to use Ricardo's phrase, upon which a seignorage of $100 \%$ has been charged. This being so, there can be no reason to suppose that they will ever be presented for cash in large quantity; for if they really become current, it will be as the necessary pocket money of every-day dealings. It is probable that the convertibility of such an issue would be amply secured by a reserve of $20 \%$ of gold. ${ }^{1}$ Why should such notes be presented for cash? Not to obtain change in gold; for they are legal tender and represent the gold unit coin. Nor to obtain gold for export; for the $£ 1$ notes will be in constant circulation, and will not lie anywhere in such large quantities as to be easily obtainable. Those who want gold for export will find it more convenient to present the larger notes. The suggestion has indeed been made that the $£ 1$ notes would be in the hands of persons more liable to panic; but it is putting a heavy strain on the imagination to ask us to conceive a general distrust of Government legal tender notes. There is, in short, an essential difference between $£ 1$ notes and larger ones in respect of the reserve required to secure them; a difference which tells powerfully in favour of the particular plan adopted by Mr. Goschen in his attempt to utilize the note reserve for banking emergencies.

Mr. Goschen is perhaps partly responsible for the difficulties which have been felt in regard to this so-called 'double use' of the Issue Reserve. In his speech before the London Chamber Commerce he described his new stock of gold as 'the ear-marked securities for the $£ 1$ notes.' The expression was unfortunate, and as the context clearly shows, did not precisely convey Mr. Goschen's meaning. He has since explained that his real intention was to show that there would be a security against improper inroads upon the central store of gold, in the feeling of the people in favour of maintaining unimpaired the basis of their pocket money. The explanation should not have been required by persons familiar with the principles determining the necessary amount of a note reserve. Such persons could hardly suppose that Mr. Goschen intended to rigorously 'ear-mark' $£ 20$ millions of gold, in order to secure the convertibility of $£ 25$ millions of $£ 1$ notes. Such a use of the term would also have been inconsistent with his main purpose, the use of the reserve in banking emergencies. It is even too strong to describe the present state of things, which may be said to contemplate the occasional suspension of the Act of 1844 .

Another objection commonly brought against Mr. Goschen's pro-

1 There have been many periods since the Act of 1844 when only $25 \%$ of gold was held against the larger notes. 
posals, is that they would have the effect of weakening our stock of gold. It has been urged that in the metallic pocket money of the nation we have a last or ultimate reserve on which we might fall back, in desperate times, as Pitt did in 1797, by substituting for it inconvertible paper. But this objection only holds against the proposed issue in so far as it is fiduciary. So far as it is on a gold basis, we still have the gold, and so centralized as to facilitate such an operation as Pitt's, if it ever again became expedient. It is no doubt true that so far as the issue is a fiduciary one, gold might leave the country; but it is not really essential to Mr. Goschen's scheme that any part of the issue should be fiduciary. It is purely a question of ways and means, of the provision for the cost of maintaining the issue. The expense involved might be met in other ways : e.g. by a small tax upon bankers in proportion to the total amount of their liabilities. But the whole point is a very small one. It is very improbable that so much as five millions of gold would leave the country in this way, while the efficiency of what remained would be greatly increased.

This brings us to the question whether the issue of $£ 1$ notes would be acceptable. No doubt this largely depends upon the way in which it is approached and recommended by the bankers. But it is difficult to believe that it would long be unpopular in England, in face of the strong preference shown for such notes in Scotland and America. It seems certain that $£ 1$ notes would at least displace the present circulation of $£ 1$ postal orders. Mr. Pownall raises a small objection to the issue, not unimportant from the bankers' point of view. Sovereigns can be weighed in bulk; large drafts of $£ 1$ notes for wage payments would have to be told in detail. But objections of this sort would not be pressed against wider considerations of public interest. They ought not to prevent a fair trial of what both Ricardo and Jevons considered the ideal form of money in civilized countries.

In estimating the quantity which might possibly be issued, the amount of the present gold circulation is an important datum. Mr. Goschen, perhaps desiring to be upon the safe side, adopts the figure of $£ 73$ millions for this amount, which agrees closely with Messrs. Martin and Palgrave's estimate of $£ 69$ millions to $£ 75$ millions. But it is clearly shown in The Economist of January 3, 1892, that this estimate was too low; and it was subsequently increased by Messrs. Martin and Palgrave to $£ 80$ millions odd, a figure which, as The Economist of January 23 further shows, must be raised to $£ 86$ millions, in consequence of a double entry of light coin withdrawn, which seems to have crept into the calculations. Indeed by the authorities at the Mint, and by M. Ottomàr Haupt, the gold circulation has been put as high as $£ 100$ millions ; and $\mathrm{Mr}$. Palgrave himself put it at $£ 110$ millions in 1883 . There is therefore reason to think that Mr. Goschen was not unduly sanguine in assuming that if the notes were well received, as many as $\$ 25$ millions might be got into circulation.

The strength of Mr. Goschen's scheme is most clearly shown when 
we compare it with the only alternative proposals. Mr Pownall and others call upon the Government to strengthen the reserve by holding $\$ 7$ millions of gold against their savings-bank deposits. This seems an extraordinary demand. One might as reasonably ask the insurance companies to hold large gold reserves. Experience is the only real index of the proportion of reserve required in any business. Now. experience shows that no panic is to be apprehended in regard to Government savings-bank deposits, and that nothing beyond tillmoney is ever required to be held against them. Long and general depression might cause a withdrawal of these deposits, but only for purposes of current expenditure. The withdrawal would be very gradual, and the money would quickly return to the general banking system. The suggestion is really a cool request that the State should provide a large gold reserve for the. general banking system at the expense of still further reducing the already low rate of interest paid to the small depositors. It may be safely assumed that Parliament would never entertain any such proposal.

Mr. Pownall further suggests that the banks should keep a reserve in notes of the Bank of England to the extent of about 15 per cent. of their liabilities. This, as he admits, would be a costly plan. Moreover it is difficult to see what guarantee could be given that no inroads should be made upon this reserve in ordinary times. Nor does Mr. Pownall explain when, and under what conditions, he proposes that this reserve should be accessible. A reserve which is never to be touched is of course no reserve at all.

This latter objection might possibly not apply to Mr. Pownall's scheme as developed in detail; but it is conclusive against cast iron legislation of the American type, requiring banks always to hold a fixed percentage of legal tender against their liabilities. Such legislation may put some check upon the advances made by banks, and it may guarantee the existence of a valuable asset in case of liquidation; but an asset of this sort is no more a reserve than the hoard of a miser is a provision for old age. A reserve that must always be reserved is a. contradiction in terms. The true banking reserve is a fund of legal tender set apart to be available to meet exceptional demands.

$\mathrm{Mr}$. Gairdner's suggestion avoids some of the difficulties of Mr. Pownall's. He would prefer to obtain his gold from the ordinary circulation by an issue of $\& 1$ notes. But failing this, he would have the principles which Mr. Goschen applies to his suggested issue of these notes applied to the existing issue of notes for $\$ 5$ and upwards, whether of the Bank of England or other banks. This, upon his calculations, would involve an addition to our stock of gold of about $£ 18$ millions, the cost of which would fall upon the issuing banks, no less than $£ 8 \frac{1}{2}$ millions having to be found by the Bank of England. It would further be necessary to repeal the Act of 1844 in favour of the Scottish system. Mr. Gairdner's plan therefore would involve great changes, and would throw the cost of strengthening the reserve 
wholly upon the issuing banks ; the largest banks, and those declaring the highest dividends, coming off scot-free. After all, it gives no real security that a larger reserve will be held in proportion to the total liabilities, issue and banking together; and in any case it provides no second reserve. The Scottish system, no doubt, works very well; but it is not an independent system. In the last resort it rests upon the Bank of England as its second reserve ; and no argument drawn from the Scottish system can possibly show that it is wise to dispense with a second reserve for the banking system of the United Kingdom as a whole.

Mr. Stanley Cobb's proposal seems more deserving of consideration. Mr. Cobb is satisfied that no measure which merely aims at keeping an increased reserve on present lines will be adequate, and declares at once for a second reserve. But he objects to Mr. Goschen's plan as tending to increase the already excessive dependence on the Bank of England; and proposes that the banks shall form an independent reserve of their own by a contribution of $2 \frac{1}{2}$ per cent. on their total deposits, which. would give altogether some $£ 16 \frac{1}{4}$ millions. This reserve, however, would be of very little use, as he makes the condition of access to it that the rate of discount shall be 10 per cent. There has been no 10 per cent. rate since 1866, and it may be hoped that in future we shall manage to avoid such rates altogether, in which case Mr. Cobb's reserve would be merely dead weight. Further objections to his scheme, as well as to those of Mr. Gairdner and Mr. Pownall, are that it would involve a considerable charge upon the banks, and a considerable extra drain upon the gold market, causing a tendency to a depression of prices, and consequently of trade. Both these difficulties might be avoided if the banks were permitted to issue $£ 1$ notes to the extent of their share of this second reserve, such notes being issued and secured upon uniform conditions, laid down by the State, and then declared legal tender. This might be a fair scheme, but it is not Mr. Cobb's; and it would probably be more difficult to work than $\mathrm{Mr}$. Goschen's, while it certainly involves a wider departure from the policy of the Act of 1844. It must always be borne in mind that there are only two ways of forming a large gold reserve. The gold must either be taken out of the circulation and replaced by notes, or it must be scrambled for in the European market, and not only paid for at someone's expense-a comparatively small matter-but made more scarce than it already is, a matter of public concern. With the exception of Mr. Gairdner, few of Mr. Goschen's critics seem to see what a delicate matter it is to increase the strain on gold. Mr. Cobb proposes to take some $£ 16$ millions off the market, Mr. Gairdner £18 millions, and Mr. Pownall, if I have rightly followed him, so large a sum as $£ 40$ millions. Yet the probability of a considerable demand on Austrian account, and the profound uncertainty of the position in the United States, and even in India, might well make the most light-hearted hesitate before setting out upon such a policy. 'It is one of Mr. Goschen's great merits that 
he has always been alive to the international character of monetary questions, and he shows it in this case by his choice of a modus operandi which leaves the value of gold undisturbed.

In the course of the discussion, the bankers' balances at the Bank of England have naturally been the subject of much comment, and suggestions have been freely made in regard to them. Since the year 1876 the Bank of England has made no separate return of these deposits. But in that year, out of a total of $£ 30 \frac{1}{2}$ millions of deposits, $£ 12$ millions were returned as bankers' balances. Mr. Pownall shows that sixty-one times, between 1847 and 1877, the Bank reserve was not sufficient to meet the London bankers' balances ; and that when the return ceased, in 1877, these balances had, on the average, amounted to more than 75 per cent. of the Bank reserve; although that reserve stood at the high figure, relatively to general English banking practice, of considerably over 40 per cent. It is therefore urged that the Bank ought to keep these balances intact in a separate fund. But it is hardly reasonable that the Bank of England, which only makes a modest profit of 10 per cent., is to be prevented from using so large a proportion of its deposits, while the depositing banks are trading up to the hilt upon theirs, and in some cases declaring nearly twice the percentage of profit.

Still, it is worth consideration whether it is not desirable to isolate and emphasize the bankers' balances more than is the case at present. There should certainly be a separate return of their amount, as up to 1876 ; and there is something to be said for their being kept elsewhere than at the Bank of England. A portion of these balances, at any rate, might be kept at, or for, the Clearing House. There is no necessary connection between the clearing and the Bank of England; but a certain amount of money must be deposited somewhere to serve as the basis of those book credits and debits which finally balance the clearing transactions. If these deposits were kept for the Clearing House, with a separate account, they might serve as a sort of Clearing House till-money in ordinary times, and be available as reserve for short periods of exceptional strain, during which credit might perhaps be given to one another by the banks for the balances payable on the clearing, the actual settlement being allowed to stand over. In any case, there is something to be gained by indicating how much of the bankers' balances really represents the till-money required to meet the clearing transactions. Suggestions of this kind might be adopted in conjunction with such a scheme as Mr. Goschen's, to which they could not pretend to provide an adequate alternative.

The question may also be raised whether the new $\& 1$ notes, and perhaps legal tender notes generally, should not be issued through the agency of the general banking system. It seems clear that legal tender notes should be centralized in regard to their general administration and uniform in character. So far we may adopt Sir Robert Peel's ideal, even if we do not entirely accept the grounds on which he put it forward. But there is much to be said for actually issuing such notes 
through the agency of the deposit banks generally, subject to the uniform conditions imposed. The circulation might in this way be more carefully and intelligently adapted to local and seasonal needs, and such elasticity would have a steadying effect on the discount rate. To such a plan none of the objections urged against country issues in 1844 would now apply. The over-issue by small unintelligent banks, so much dreaded after the experiences of 1826 , would be prevented by the general conditions imposed on all issuers; and moreover the whole character of English country banking has changed since 1826; the legislation initiated in 1826 and 1833 having left English banks free to organize themselves in the natural form of large joint-stock companies, operating over wider areas, and managed upon sounder and more public methods. It would be necessary to offer some inducement to the banks to undertake the trouble of such issue agencies. The matter might be arranged by permitting a maximum circulation to each bank, four-fifths of the average yearly circulation to be accounted for by gold in the Issue Department, one-fifth to be against securities. The cost of maintaining the notes might be thrown upon the Issue Department, and defrayed by a reduction of the annual sum now payable by the Bank of England to the State. Upon the whole, however, it must be admitted that an arrangement of this kind, though there is something to be urged in its favour, would complicate Mr. Goschen's scheme, and perhaps increase the fiduciary element in it. It may be better, too, to wait a while, and not to use the banks generally as an issuing agency until the consolidation of banks has made further progress, and the old note issues have dwindled into insignificance.

One of the most important passages in Mr. Goschen's speech at the London Chamber of Commerce was addressed to the bimetallists, and it is interesting to consider in what way his scheme is related to the objects they have in view. There is no doubt that when Mr. Goschen's proposals first appeared, they were regarded with disfavour by many bimetallists. It was thought that they indicated an intention on Mr. Goschen's part to meet the avowed deficiency of gold by a paper, rather than by a silver policy; and further disappointment was expressed when it was announced that the suggested issue of ten-shilling notes based upon silver was to be dropped. But as the bearings of Mr. Goschen's proposals are better appreciated, it will be seen that there is much to recommend them to those who do, as well as to those who do not, desire to see silver used as standard money. They will reduce the pressure on gold, and so far, no doubt, they tend to make gold monometallism less impracticable. On the other hand, they increase the amount of the Issue Reserve, and thus they increase the value of the offer to hold one-fifth of this reserve in silver; an offer originally made by a Liberal Government as England's contribution towards the establishment of international bimetallism, and very emphatically endorsed by Mr. Goschen on behalf of a Conservative Government in his Chamber of Commerce speech. It is only in this form of bank reserve that there 
will ever be any considerable increase in the monetary use of silver in this country; and the more extended use of paper is a condition, rather than an alternative, to the wider monetization of silver. As for the ten-shilling notes, it is doubtful whether they would be popular; and it is most undesirable that the enlarged use of silver should be associated with an unpopular form of currency. Nor would it be desirable to institute two kinds of issue reserve, which, until bimetallism were established, would have different degrees of efficiency. It does not seem, then, that bimetallists have any special reason to be dissatisfied with Mr. Goschen's proposals, or to regret the simplification which they have undergone.

What indeed most calls for regret is that the process of simplification has not been carried still further. The conclusion to which this brief review tends is that Mr. Goschen's scheme is not open to any serious objection so far as its general principles are concerned, nor in the least likely to be set aside in favour of any alternative proposal at present before the public. But there are two grounds upon which a certain hesitation in accepting it may reasonably be felt. The scheme appears to be unnecessarily complicated; and we are without definite information on a point of vital importance, viz., the terms on which access may be had to the second or issue reserve. These seem to be the most doubtful points in the scheme, and it remains, in conclusion, to offer a few observations upon each of them.

There seems to be unnecessary complication in the limits which Mr. Goschen has prescribed for the coming into operation of the various new powers which he proposes to create. Why, for instance, should he stipulate that there must be no fiduciary issue of $£ 1$ notes until £38 million notes are issued upon the old footing? Apparently because he is anxious not in any circumstances to risk an increase in the proportion of the fiduciary issue. But this proportion has diminished since 1844, and the possibility of a slight increase in it is not so serious a matter as to balance the inconvenience of this limit; which, as Mr. Pownall has shown, would lead to uncertainty, perhaps to confusion, in the working of the issue. Again, why are the new powers of relief issue not to be available until the stock of gold in the Issue Department amounts to $£ 30$ millions? This again seems an unnecessary precaution; and, as Mr. Pownall points out, it might prevent the operation of the new powers exactly when it was most required. It would, for instance, have made the scheme inoperative in 1857, even if $£ 25$ millions of $£ 1$ notes had then been in circulation. Thus, if Mr. Goschen's scheme, with its present limits, had been in force in 1857, it would none the less have been necessary to suspend the Bank Act in that year. Why, in short, should any distinction whatever be drawn between the conditions of issue of the two kinds of notes? It is difficult to understand how far Mr. Goschen does make such a distinction, since in his letter to Mr. Montagu he says that the $£ 1$ notes are not to have a special stock of gold. Apparently the issues are only 
distinguished in regard to the extent to which they are to be of a fiduciary character. It would seem that Mr. Goschen has been led to complicate his proposals by an unnecessary tenderness for Peel's Act, and a desire to represent his scheme as an addition to that Act rather than a modification of it. But surely the Act of 1844 is from its very nature one which no statesman need hesitate to amend. Its empirical basis shows that it was drafted to meet the special requirements of its own day, and cannot consequently be perfectly adapted to the greatly altered conditions of the present time. There is much force in the suggestion of The Economist for January 23, 1892. Why not permit the Bank of England to issue $£ 1$ notes upon the present basis? It might be objected that the Bank would receive no consideration for the trouble of managing the new issue. This might however be arranged in either of two ways. The amount of the fiduciary circulation might be made to vary automatically in a definite relation to the average yearly additional issue; or the State might remit part of the annual payment of $£ 180,000$ now made by the Bank.

It may be urged that some, if not all of these points, are matters of detail, not of principle, more fit to be discussed in Committee than on the Second Reading. But this cannot be said of the question of the terms of access to the Issue Reserve. This is a really fundamental point, determining the whole character and scope of the scheme. Until it is decided, it is impossible to say whether the scheme will effect what is really wanted, or even have any effect at all. What is to be the main purpose of the second reserve? Is it to be strictly a panic reserve, only available at times of absolute crisis ; or is it to be generally available to prevent injurious monetary strains? In other words, is the rate fixed for access to the reserve to be a comparatively low rate, fixed by the point at which the difficulty of obtaining accommodation becomes a serious obstacle to the ordinary business of the country; or is it to be a high rate, and are we aiming merely at relieving strains which threaten the entire collapse of the credit system? Are we to follow the lines of Mr. Lowe's proposal in 1873, fixing the minimum rate at 10 per cent. or even higher ; or shall we follow the example of Germany, where relief begins at a 5 per cent. rate?

If the higher rate is chosen, we shall not be one whit better off than we already are under Peel's Act, except that a point of form will be saved. There would be nothing in such an arrangement to meet such a case as that of the Baring strain in 1890. But mere protection against a general financial collapse is not the highest aim of sound banking. The Economist asks why the State should concern itself about the solvency of banking more than with that of any other kind of business. The answer is that it is the regular working of the banking system, rather than the solvency of banks, with which the State is concerned; and for the reason that the prosperity of trade and the regularity of employment depend upon this steady working. It is not enough that banks should be able to maintain their own solvency 
at the cost of the insolvency of their customers, by charging prohibitive discount rates, or otherwise restricting their ordinary accommodation. What we want is a machinery so constituted as to make extreme strains of this kind unnecessary. The true economic test of sound, as distinguished from merely solvent, banking, is the moderation of the average rate of discount, and still more the limited range of its fluctuations from the average. The Bank of France has a legitimate ground for self-congratulation in the fact that it was able during 1890 to maintain its rate without alteration at 3 per cent., whilst the rate in London was for some time as high as 6 per cent., and 4.55 per cent. on the average for the year.

Both Mr. Goschen and Mr. Lidderdale are alive to this consideration. Mr. Goschen's first exposition of his scheme, at Leeds, was accordingly addressed to the mercantile community generally, rather than to bankers specially, and it contained the following important passage :' It is all very well for banks to give facilities to their customers in good times, but a customer looks to his banker for facilities when the pinch comes; and if, when the pinch comes, the bank itself is obliged to draw in its resources, to call in money, it disturbs all mercantile arrangements, and the bank is really not assisting the country, but is thwarting the interests of the banking and trading communities.' 1 Mr. Lidderdale observed on March 12th, 1891, that "where reserves are small, any "pull" upon them by withdrawals from foreign countries necessarily makes a large reduction in our reserve, and . . . as that reserve is practically the reserve of the country ... . the reduction has a much larger effect upon the value of money than it would have if the balances were larger.' Mr. Gairdner takes a similar view, and thinks we ought to be able "largely to diminish those oscillations in the rate of discount which so perplex and annoy the regular trader.'

It is admitted then by high authorities that this is the essence of the question of reserve. But if the real object of scientific, commercially efficient banking is the stability of discount rates, then the relief issues should commence at the point where the discount rate becomes injurious to trade. A limited amount of relief should be afforded on fairly easy terms, the terms becoming more stringent as the assistance required increases. The operation of the reserve should be preventive rather than remedial. Mr. Goschen's language does not give the impression that he inclines to this view. It is expressly opposed by Mr. Pownall, who goes so far as to say with Mr. Lowe, that the rule should never permit of access to the reserve when the exchanges are against the country. But this is to say that the reserve shall be useless in almost every case where its aid is likely to be required. The usual cause of serious pressure in England is the withdrawal of gold on foreign account; local panics are comparatively rare and easy to deal with. The answer to Mr Pownall's objection is well stated by Mr. Gairdner. 'A demand for gold from abroad causes a diminution, not.

1 Revised edition of Leeds speech. Effingham Wilson, 1891, p. 17. 
in the circulation, which is regulated by wholly different influences, but in the deposits; and the true mode of counteracting it is to raise the rate of discount, whereby prices are lowered, and imports of gold take the place of imports of other commodities.' The rise need not be sudden or excessive. In other quarters it seems to be feared that if the system works too smoothly, men will be tempted to 'speculate up to the limit' at which relief begins. This is one of those objections which are brought against every proposal for improvement, and to which no answer need be given. So much of original sin remains in human nature that increased facilities of action, of whatever kind, are generally liable to some abuse. The banks have it largely within their power to check speculation, and would no doubt exercise their power, whether rates were stable or fluctuating. It is probable that the London market is too much exposed to foreign drains to make it possible to adopt the German system, under which the fiduciary issue can be indefinitely extended upon the payment of 5 per cent. to the State. But there is no reason why the advances from the second reserve should not commence at something like this rate. The scale might be fixed on the principle recommended by Mr. Samuel Montagu, rising with the amount of the total sum advanced; or it might vary in some inverse ratio to the amount of gold left in the reserve after the advance was made.

If such an arrangement or anything like it were embodied in Mr. Goschen's proposals, there can be no doubt that they would substantially improve the financial position of the country; and this without any appreciable expense, and, what is more important, without any pressure on the scanty stock of available gold. No doubt our market will always remain exceptionally exposed to disturbance on account of the exceptional facilities afforded in London for the export of gold. That this makes London a convenient place of call for international financiers, and attracts certain deposits which might otherwise be held elsewhere, is highly probable. Whether these considerations are suffcient compensation to the nation at large for the injury resulting from the disturbance to its money market is another matter. At any rate, it is these international deposits that really press upon the banking reserve, not savings-bank deposits; and it is not surprising that in Germany and France some restriction should be placed on international movements of gold. Words which Mr. Pownall has used in another connection are very pertinent here. 'Our money market is sensitive because we choose that it shall be so.' Everything is sacrificed to facilitate international operations in English gold, and yet, when there is anything to be gained by international arrangement, our high financial authorities are resolutely insular. If, then, after the best possible system of reserve has been established, a certain special sensitiveness should still characterize the English market, it must always be remembered that this is the natural result of our traditional habits of finance. Whether our difficulties are caused by the insufficiency of 
our reserve, the facilities afforded for the export of gold, or the want of an international understanding as to the monetary basis, the remedy is in our own hands. 'Our money market is sensitive because we choose that it shall be so.'

H. S. FoxweLL

\section{One Pound Notes and the Metallic Reserve of the Bank of EngLand.}

Everybody who understands or has read anything about the principles which form the basis of every good currency system, will be indebted to Mr. Goschen for having had the courage, displayed at Merchant Taylors' Hall, on the 2nd of December, 1891, to endeavour to remove the existing and long-standing prejudice against lowering further the denomination of the notes issued by the Bank of England. His mind was so full of the pro and con arguments that, perhaps, it is not to be wondered at that he did not say much, if anything, directly upon the question of whether or not it is wise in principle to issue a currency of $£ 1$ notes. Perhaps, as a political economist, he thought it superfluous to cite Adam Smith or John Stuart Mill. But I am inclined to think such citations would have laid a good foundation for his superstructure, and would have been useful in the sense of showing everybody that the best judges are of opinion that that system of currency is the best which is the least trouble to carry about and transmit, and which is the least expensive to maintain in efficiency. What this expense is in the case of gold, if the coins were kept up to legal weight, may be gathered from the fact that a Lombard Street banker told the writer only recently that fifty per cent. of the gold their cashiers took across the counter was below the legal weight. He said, besides, that much of the gold coming back from the Continent was found to have been filed. The argument in favour of further extending the note issue to $£ 1$ notes is supported on other grounds than those above referred to, and I question if the hearers of the Chancellor of the Exchequer on the occasion referred to estimated at its full value his remarks on the subject of the cheque system. What does the evidence he adduced go to show? why that the desire of everybody who is not warped in their judgment by sentiment and fossillized prejudice, does all he can to facilitate the interchange of commodities, and to remove trouble and friction from the path of all who have to transact the domestic or international business of this life. The Chancellor of the Exchequer said that he was prepared to assist in carrying out this project of a $£ 1$ note issue, if the public will have it and use it. The answer to his own query stands out in bold letters in what he said about the extension of the cheque system. Of course the public will have the $£ 1$ notes and use them gladly. Other nations who are less practical than we are use them, and why should not we do the same? There seems to be so little doubt on the 